Kinestetik : Jurnal Ilmiah Pendidikan Jasmani $5(2) 2021$
Kinestetik : Jurnal Ilmiah Pendidikan Jasmani
https://ejournal.unib.ac.id/index.php/kinestetik/index
DOI: 10.33369/jk.v5i2.13154

\title{
DEVELOPMENT OF A GYMNASTICS MOVEMENT THROUGH EXPLORATION OF THE CULTURAL VALUES OF THE ACEH RAMPOE DANCE IN LANGSA CITY
}

\author{
Yoki Afriandy Rangkuti*1, Rizkei Kurniawan ${ }^{2}$, Dedi Andriansyah ${ }^{3}$, Muhammad Fauzan \\ Isma $^{4}$ \\ ${ }^{124}$ Universitas Samudera, Aceh, Indonesia \\ ${ }^{3}$ Universitas Negeri Medan, Sumatera Utara, Indonesia
}

Info Artikel

Article History :

Received : October 2020

Revised : January 2021

Accepted : June 2021

Available online: June 2021

Keywords:

Development, Gymnastics, Cultural values, Aceh Rampoe Dance

\begin{abstract}
This study is a study that explores cultural values and develops a gymnastic movement that originates from the Aceh Rampoe dance in Langsa City. The research method used is a combination of qualitative research and development (Research \& Development) from Brog and Gall. In the part of exploring the cultural values of the Rampoe Aceh dance, qualitative research methods are used with a holistic approach through in-depth interviews and direct observation at dance studios. Historical analysis of this dance is not a traditional Aceh dance that has existed for a long time. accordance with the terminology of the naming "Rampoe" which in Indonesian translation means "mixture", then this is the essence of the Aceh Rampoe dance. This dance is created and developed by combining or a mixture of several types of traditional Acehnese dances, such as the Likok dance, the Saman dance, and the Seudati dance. At each movement and the translation of the meanings contained in the Rampoe dance, it shows a variety of life messages related to the orientation of cultural values, namely first, the connection between the essence of a life of the Acehnese people $(\mathrm{MH})$, and secondly related to the nature of the relationship between the Acehnese people and others. human (MM). A cultural value orientation that leads to the essence of life in oneself which is a creature that is created and has the creator, as well as relationships with other creatures (humans). So it requires a way to remind oneself to build a relationship between the creator and the creator (Allah SWT), which is accommodated by the element of religiosity that is felt in the lyrics of the Rampoe dance which are full of recitations of shahada and Shalawat. The Rampoe dance movement consists of Nyap (bending), moving steps, Rheng (horizontal movement), Asek which is a movement of turning the head from right to left, Ketrip Jaroe which is a movement in the form of snapping fingers, Nyet which is the body resting on the feet, then Dhet namely the movement of shrugging while the hand is slapped to the rhythm of the song, Gudam Kaki, and Puta Taloe, which is moving alternately between dancers.
\end{abstract}

Corresponding address : Jl, Prof. Dr. Syarief Thayeb, Meurandeh, Langsa

Lama, Langsa City, Aceh

*Corresponding email : yokikenshi@unsam.ac.id
ISSN 2685-6514 (online)

ISSN 2477-331X (print) 


\section{INTRODUCTION}

The Indonesian Central of Statistics explained in 2018 that around 714 tribes are living in Indonesia. So that this affects the diversity of cultural heritage resulting from these tribes. one of the well-known cultural heritages of these tribes is in the field of traditional dances. The Acehnese tribe is one of the tribes in Indonesia which is so famous for its traditional dances. There are many dances from the Acehnese tribe that are already respected in the national and international arena, such as the Saman dance, the Seudati dance and so on. The Aceh Tourism Office in 2015 recorded various types of dances in all regions in the Province of Nanggroe Aceh Darussalam, including the Langsa City area where there were 10 types of traditional dances. One of the interesting traditional dances to explore in the city of Langsa is the Aceh Rampoe dance. By the origin of its name, Rampoe which means mixture, is a mixed dance or a series of dance movements from various types of traditional Acehnese dances.Aceh Rampoe Dance is certainly not only a gesture that has aesthetic value, but a gesture that also has a philosophical value that can describe the cultural values of the Acehnese ethnic life in it.

It should be understood that the dance movement in terms of its role is a motor activity that is quite similar to that of gymnastics. Gymnastics is a physical activity that is useful in helping to optimize the development of individual motor skills similar to dancing movements. These two things have a lot in common even though they are different elements. The movement of gymnastics involves the performance of the motion which of course requires strength, speed, harmony of physical movements that give fitness results to the body. So far, researchers have seen that gymnastics is still considered a part of sports and have reviewed the scientific studies of Physical Education. But actually, this activity to strengthen the body will be very interesting if it is not just motoric movements, but there are cultural values from elements of traditional dances such as the Aceh Rampoe dance that accompany it.

So on this basis it is necessary to make efforts to reveal and explore the cultural values contained in the Aceh Rampoe dance. At the same time, came up with a design for the development of a gymnastic movement that was derived from the cultural values of the Aceh Rampoe dance in Langsa City.

\section{METHODS}

The method in this research is divided into two strands, namely in the part of exploring the cultural values of the Aceh Rampoe dance, qualitative research methods are used with a holistic approach with a life history approach model. The life history approach is carried out by indepth interviews with traditional leaders, studio owners, dancers and informants who are considered to understand the ins and outs and meanings of the Rampoe Aceh dance.

Then in the research section of the development of gymnastics movements 
through exploration of the cultural values of the Aceh rampoe dance in Langsa City, it consists of three stages and design steps whose descriptions have been and are aligned with the objectives and conditions in the actual field, the three stages are predevelopment, development and application. In general, the results of a development research are to produce new products that are used in learning activities to make it easier to convey material by Yoki A.R (2019). the product was consulted to the expert to then look for the validity and reliability of the product used in the study by Rizkei Kurniawan (2013)

\section{Participants}

Informants in this study were divided into two classifications, namely key informants and regular informants. As for the key informants in this study are the owner of the SIDOUM dance studio, the owner of the Mutiara Pasai dance studio and also traditional leaders. Meanwhile, the regular informants in this study were the dancers who had performed the Aceh rampoe dance.

\section{Sampling Procedures}

The sample in this study was selected by means of purposive sampling. Determination of the sample in the form of Pusposive sampling aims to be directed to search the research information data. The selected informants have the qualification objectives that lead to the informant's understanding of the Rampoe Aceh dance.

\section{Materials and Apparatus}

In this study, information collection was carried out by means of direct observation at the studios that train the Rampoe dance, namely Sanggar Mutiara Pasai and SIDOUM Studio which are also art laboratories in Langsa City. Then extracting information is carried out in the form of in-depth interviews in an unstructured manner to informants by preparing an interview guide (informant guide), and supported by the results of photo documentation and video of the Aceh Rampoe dance performance.

\section{Procedures}

Researchers visited one of the studios in Langsa city which was traced to maintain the existence of the Rampoe dance, namely Sanggar Mutiara Pasai. The studio is chaired by Isra Fahriati (47). The researcher then starts extracting information by first conveying the aims and objectives of the research to the informants, then the researcher begins to convey some of the questions that have been prepared in the interview guide to the informants. Among them are related to the existence of the Rampoe dance to date. The informant said that the desire to maintain the existence of the Rampoe Aceh dance was accommodated through an Art Performers Movement (GPS). A movement formed by Acehnese artists that aim to maintain and exist Aceh local arts and one of them is the Aceh Rampoe dance. This is inseparable from the swift flow of global arts which are currently easily consumed by the younger generation. So that the rapid development of technology in bringing all information related to global arts, becomes a big challenge for the existence of local arts. 
After interviewing informants regarding the existence of the Rampoe dance, the cultural values contained in the Rampoe dance, then the researcher observed directly (participatory observation) the Rampoe dance performed by the Sanggar Mutiara Pasai dancers to be able to witness the dance movements firsthand.

\section{Design or Data Analysis}

In analyzing research data regarding the cultural values of the Aceh Rampoe dance, it has been suggested by Foley that the researcher connects the problem understudy to the context. The research context is an analysis of the Rampoe dance movement which can then reveal the cultural values contained in each movement. Furthermore, the deepening of data related to the research results is analyzed again through Spradley's (2015) ethnographic analysis techniques, namely domain analysis, taxonomic analysis, and component analysis to further explain the cultural concrete evidence and the values contained therein (Spradley. 2015 : 6-7)

\section{RESULT}

Langsa City is one of the cities in Nanggroe Aceh Darussalam Province which is famous for having various cultural heritages. One form of cultural heritage that is still being preserved is the local art of traditional dance. Based on data from the Langsa City Tourism Office in 2017, 10 types of dances are currently included in the local contemporary classification, namely: (1) Japin Dance, (2) Rampoe Dance, (3) Peumulia Jame
Dance, (4) Seudati Dance, (5) Top Pade Dance, (6) Rapai Geunta Dance, (7) Seudati Tunang Dance, (8) Ranub Lampu, (9) Rapai Daboh, and (10) Rapai Geleng Dance

These ten dances indicate that Langsa City is so rich in local arts, especially in dance. This can be a projection not only as a cultural heritage that needs to be preserved but also as a form of support for Langsa city tourism, especially in the aspect of cultural tourism. In this study, the dance that became the focus and locus of the research team was the Aceh Rampoe dance.

1. The existence of the Rampoe Aceh dance in Langsa City

Searching for information about the origin of the local arts of the Aceh Rampoe Dance reveals that historically this dance is not an original traditional dance that has existed for a long time. Even the journey of the Aceh Rampoe dance is still shrouded in contradictory dynamics whether this dance is classified as a traditional dance or a creative dance. However, along with its existence which is always presented by the studios in Langsa City, this dance can then be accepted as part one of Aceh's local arts.

Langsa City is the city where the Aceh Rampoe dance was born. The artists of Langsa City became important actors in the emergence of this dance. In the late 1980s, artists named Mukhtar Bireun, Hamdan Bireun, Asnawi Idi, Abubakar A.R, Syeh Lagenta, and Ayeh Rais 
developed this dance at the Pintoe Aceh studio, Langsa city. accordance with the origin of the name "Rampoe" which in Indonesian translation means "mixture", then this is the essence of the Aceh Rampoe dance itself. This dance is created and developed by combining or a mixture of several types of traditional Acehnese dances, such as the Likok dance, the Saman dance, and the Seudati dance.

The mixture of movement elements from several traditional dances provides its aesthetic value to the appearance of this rampoe dance movement as a whole. So that is one type of dance, the audience who watches this dance can enjoy a variety of aesthetic values in other dances. In addition to presenting the beauty of the movements of various types of dances into one dance, the Rampoe dance also still presents the nuances of teaching about elements in Islam in every verse that follows the music and dance movements. So that the homogeneity of Islam in Acehnese society and the strength of the teaching of Islam make one supporting element of why this dance is very well accepted by people in the city of Langsa. Besides, as a result of local migration that is often carried out by residents from one place to another in the Aceh area, gradually this dance has begun to be recognized by other people outside Langsa City. Although the results of the Aceh Arts Workshop in 1981 still did not include this dance into the art section of Aceh, the rampoe dance was often performed in every formal event and regional arts, but practically this Aceh Rampoe dance has been considered a part of Acehnese arts.
Researchers visited one of the studios in Langsa city which was traced to maintain the existence of the Rampoe dance, namely Sanggar Mutiara Pasai. The studio is chaired by Isra Fahriati (47). The researcher then starts extracting information by first conveying the aims and objectives of the research to the informants, then the researcher begins to convey some of the questions that have been prepared in the interview guide to the informants. Among them are related to the existence of the Rampoe dance to date. The informant said that the desire to maintain the existence of the Rampoe Aceh dance was accommodated through an Art Performers Movement (GPS). A movement formed by Acehnese artists that aim to maintain and exist Aceh local arts and one of them is the Aceh Rampoe dance. This is inseparable from the swift flow of global arts which are currently easily consumed by the younger generation. So that the rapid development of technology in bringing all information related to global arts, becomes a big challenge for the existence of local arts. After interviewing informants related to the existence of the Rampoe dance, the cultural values contained in the Rampoe dance, the researcher then observed directly (participatory observation) the Rampoe dance performed by the Sanggar Mutiara Pasai dancers to be able to witness the dance movements firsthand.

2. Movement patterns and their meanings in the Aceh Rampoe dance series in Langsa City

The historical appearance of the Aceh Rampoe dance is inseparable from the 
inspiration for the amalgamation or mixture of various other Acehnese traditional dances, including the Seudati dance, Likok dance, and Saman dance. So that the movement pattern of the Rampoe dance is not much different from the traditional dance which is the main mix of dance, because every rampoe dance movement always has a chapter that shows the characteristics of these traditional dances. The results of interviews by researchers with studio owners as well as rampoe dance trainers explained that although the movement patterns and all dance activities are a mixture of several types of dance, it does not mean that they take the elements in each of these dances. However, all the patterns of movement and activity in the Rampoe dance performance are implied to have a meaning in it.

All things related to a series of traditional activities as well as cultural activities and forms, by Geertz (2001) it has been explained that the series in customary or traditional activities is always inseparable from hidden meanings or values that can only be interpreted by the owner of the culture (tribe), religious meaning., social, and others that require an emic approach in understanding it (Geertz. 1996: 114)

The series of movement components in the Aceh Rampoe dance include:

\section{1) Greetings / Saleum}

The Rampoe dance always begins with a greeting or a saleum, just like other traditional Acehnese dances. The state of religious homogeneity of the Acehnese people makes each dance that is performed inseparable from the elements of Islamic religious teachings, one of which is greeting. Greetings or saleum are interpreted as a tribute to the guests who have come, the audience, and the organizer of the activity. In accordance with the lyrics that were performed during the greeting "salamualaikum jame baro troh, Tamong jak piyoh ne deuk bak tika, Nyoe mpat na ranub di dalam bungkoh, Neu cok ne pajoh buloeng berate" which means "asalamualaikum to newly arrived guests, please sit down the place that has been provided, this is the betel that we offer, please taste it, don't a has newly-arrived position of the dancer"

The layout of the dancer's position so shows the inspiration of the Likok dance, which is characterized by a dance leader called a sheikh, and some dancers who are behind the dance leader called aneuk syekh. in the prayers performed by Islam. The position of the congregation is always behind the priest and follows every worship movement made by the priest, as well as the dancers. Another meaning from the results of the researchers' interviews related to this arrangement is that it is not just an analogy about the priest and the congregation, but also related to the leadership of a leader and the unity of vision and direction between those being led by the leader. This is what will become an order in social life, like this also with this rampoe dance which will get harmony and order in every appearance if there are one direction and one vision of the aneuk sheikhs with the sheikhs.

3) Nyap

Bending in Nyap means bending your knees while lowering your body, the movement is like a flat, up and down motion. Based on the results of interviews, this movement has the meaning that for 
Acehnese, in carrying out daily work or actions, it should be started carefully and slowly (not recklessly), then when they understand the work, it is done in a fast and Don't ask slow down

\section{4) Move steps}

In the step part of the Rampoe dance component, the dancer will usually perform a step movement with details of three steps forward, three steps backward then added with half steps to the front left and then back but still with the body position and chest bent. This implies that related to daily actions, it should be directed or ordered and orderly.

5) Rheng

Rheng is a horizontal movement that follows a count of four and two and ends with a motion. Having variations and considerations in determining the life policies to be pursued is the meaning contained in the Rheng movement.

6) Asek

Asek is a movement to turn the head from right to left, then turn left and then turn right. This movement contains the meaning of hope in the life of the Acehnese people to always be accompanied by happiness and joy.

7) Ketrip Jaroe

This Ketrip Jaroe motion is a movement in the form of snapping fingers which will then make a sound. The meaning contained in this movement is related to the joy and pleasure that should be shown in the life of the Acehnese people.

\section{8) Nyet}

This movement is similar to the nyap movement at the beginning, namely with the form of body weight resting on the feet, it's just that the shallowness of the foot moves from the right foot to the left. However, this depends on the lyrics of the songs played in the Rampoe dance. The meaning contained in this movement is a form of joy and excitement that occurs in life so that it is then expressed in body movements.

9) Dhet

This Dhet movement is a hallmark of the traditional Aceh dance movement. Namely shrugging while your hands are smacked or slapped to the beat of the song. Similar to the meaning of some of the movements above which is more of a form of joy, so is the meaning of the Dhet movement. But the form of joy and joy is shown or expressed in shoulder movements.

\section{0) Foot Gudam}

This movement is the movement of the dancers' feet simultaneously in stamping their feet so that they will make a sound. The meaning contained in this movement is the meaning of firmness in making any decisions in life that should be firm and fast.

\section{1) Puta Taloe}

This movement is described as walking alternately between dancers which can be interpreted as rotating the rope. The meaning contained in this movement is an affirmation that in the life of the Acehnese people there is no form of stratification and grouping between those who have economic conditions who are well off and those who are less fortunate, must mingle with each other and continue to help each other.

All the meanings contained in the components of the Rampoe dance movement imply a direction of life in the Acehnese society that must uphold high 
nobility and personality norms. Controlling behavior as well as vision and mission in understanding life. This shows how flexible the function of the Aceh Rampoe dance is. Not only as a medium of entertainment but also full of preaching and teaching to the audience presented by the dancers.

3. Cultural values contained in the Aceh Rampoe dance in Langsa City

The Aceh Rampoe dance is a cultural manifestation of the Acehnese people, not just a creative dance from the combination of several traditional dance movements, but also contains so many cultural values in it. C. Kluckhon (1987) describes that every cultural value system in each culture contains five basic problems in human life. The five basic problems in human life which are the basis for the framework of variations in the cultural value system are: (1) The problem of the nature of human life (MH), (2) The problem of the nature of human work (MK), (3) The problem of the nature of the human position in space-time (MW), (4) The problem of the nature of human relations with the natural surroundings (MA), (5) The problem of the nature of the relationship between humans and others (MM), Kluckhon also explains that a cultural value system is often in the form of a world view or world. view for humans who embrace it. The life view usually contains a portion of the values held by a society, which are selected selectively by individuals and groups in society (Koenjaraningrat. 2016: 28)

At each movement and the translation of the meanings contained in the Rampoe dance, it shows a variety of life messages related to cultural values (1) the connection between the nature of a life of the Acehnese people ( $\mathrm{MH}$ ), and also (2) related to the nature of the relations between the Acehnese people with each other (MM). A cultural value orientation that leads to the essence of life in oneself which is a creature that is created and has the creator, as well as relationships with other creatures (humans). So it requires a way to remind oneself to build a relationship between the creator and the creator (Allah SWT), which is accommodated by the element of religiosity that is felt in the lyrics of the Rampoe dance which are full of recitations of shahada and shalawat. Such as the chanting of the Arabic poem "Yahuallahuallaheha allaeha allaheha laillalahum" which means "O Allah Almighty, there is no God but Allah". Still, some of the verses in Arabic cannot be separated from avoiding mentioning the sacred Allah to be profane (something that is normal)

Meanwhile, related to the cultural value of the essence of a life of the Acehnese people with each other (MM), it can be seen in every meaning of the Rampoe dance movement which leads to an implicit message for a personality or self-character that can behave well towards others. Especially in the Puta Taloe movement which has the meaning of eliminating stratification in social life. Help each other with fellow members of the community regardless of the economic situation, whether the person being helped is a capable person or not. Despite different economic backgrounds, people must also be able to mingle with each other and build unity in the social order. Because all 
humans are the same in the eyes of the creator, and what distinguishes them is only their faith. Therefore, fair treatment without distinguishing economic conditions becomes a cultural value that is implanted in the Rampoe dance to be remembered by the audience (the people of Aceh).

Without realizing it, the actual meaning implied in every movement or sequence in the Rampo Aceh dance becomes a form of character education for all levels of Acehnese society through elements of dance art. This is because the Rampoe dance is not a dance that is merely entertainment to be enjoyed, but also a da'wah in teaching and fostering a character that understands Hablum minallah (relationship to God the creator) and Hablum minannas (relations between humans). This character education is also embedded from fragments of historical stories of the previous kings of Aceh which are useful as motivation and strengthening integrity among fellow Acehnese.

\section{DISCUSSION}

The Aceh Rampoe dance, which is a dance that is a mixture of several traditional dance movements, has its beauty and cultural value in the movements in it. Discussions about the exploration of the values and meanings contained in dance movements have been carried out by many arts and cultural researchers. The latest research to reveal the values contained in traditional Acehnese dance was carried out by Linda Novalia Sihotang (2020) with the title of research on the Aesthetic Value of Dampeng Dance in the Muara Pea community, Bukit Harapan Village, Aceh Singkil Regency. The results of his research explain that Dampeng dance shows the meaning of a persistent spirit, just as the origin of the dance is a culture brought by newcomers to be well accepted by the natives.

The discussion not only explores the value in dance movements but at present, it has also been developed on a form of gymnastic movement. Like the research conducted by Desni Yuniarni and Renny Puspita Sari (2019) with the title of research on the Development of Interactive Multimedia, Animated Gymnastics Videos, Based on the Typical Culture of West Kalimantan. The results showed that children aged 4-5 years and 56 years in PAUD Anggrek, Kubu Raya Regency, were considered to be very interested in the design of a gymnastic movement that involved the typical culture of Kalimantan. This shows that discussions related to dance and the values and meanings contained in each of its movements constitute contemporary studies that are still needed in scientific research, especially research on arts, culture, and sports.

\section{CONCLUSION}

The conclusions of this study are:

1. The existence of the Rampoe Aceh dance still shows its existence through the role of local government and other elements in society. The existence of the Aceh Rampoe dance is inseparable from the function of this dance which is not only a medium of entertainment but also as a 
medium of preaching about religious values in Islam. The continued activity of workshops in Langsa City in guiding dancers and teaching about the Rampoe dance is one of the factors that support the life of this local art.

2. The meaning implied in the elements of the Aceh Rampoe dance movement is inseparable from the value and meaning of the teachings of the Islamic religion, besides that, trust in leaders (sheikhs) and also the internalization of characters in living social life in society.

3. The orientation of cultural values contained in the Rampoe Aceh dance is related to cultural values about humans (Acehnese people) and their essence of life $(\mathrm{MH})$ as creatures that have a creator, namely the values themselves to establish a relationship with Allah SWT as the creator. Besides, there is also a cultural value orientation about the essence of humans (Acehnese people) with fellow humans (MM) so that harmonious social relations can be created without any differentiation of stratification in the social relations of the Acehnese people.

\section{ACKNOWLEDGEMENT}

For the completion of this research, the researchers did not forget to express their deepest gratitude to Samudra Langsa University for helping morally and materially. Then the owners of the dance studio which is the place for this research and also the informants who cannot be mentioned one by one for their willingness to help provide information, as well as the research team who work optimally and professionally in completing the research.

\section{REFERENCES}

Arikunto S, 2012. Prosedur Penelitian Suatu Pendekatan Praktik. Jakarta: Rineka Cipta.

Borg, W.R. \& Gall, M.D. Educational Research: An Introduction,Fourth Edition. New York: Longman.1983

Geertz Clifford. 1996. Tafsir Kebudayaan. Yogyakarta : Kanisius

Husein Ali Dkk, 2002. Model Pengembangan Motorik Anak Prasekolah. Jakarta: Direktorat Olahraga Masyarakat, Ditjen Olahraga Depdiknas.

Islamiyati Rosi. 2017. Estetika Religius Dalam Tari Saman Aceh. Yogyakarta (Skripsi).

Iskandar. 2015. Metodologi Penelitian Kualitatif. Jakarta : Gaung Persada

Koentjaraningrat. 2016. Pengantar Ilmu Antropologi. Jakarta: Rineka Cipta.

Kurniawan, R. (2013). Persepsi Orang Tua Terhadap Sekolah Sepakbolaptp. Wilayah I Sumut Tahun 2013 (Doctoral Dissertation, Unimed).

Marzali Amri. 2017. Antropologi \& Pembangunan Indonesia. Jakarta : Kencana

Maulana Roby Al Hakim, Lailatul Rohmah (2018) Pengembangan Fisik Motorik Melalui Gerak Tari Di Kelompok B Ra Dwp Uin Sunan Kalijaga Yogyakarta. Jurnal Ilmiah Tumbuh Kembang Anak Usia Dini Golden Age Vol. 3 No.4.

Novalia Linda Sihotang 2020. Nilai Estetika Tari Dampeng Pada Masyarakat Muara Pea Desa Bukit Harapan Kabupaten Aceh Singkil. Jurnal Unimed

Ranjabar Jancobus. 2014. Sistem Sosial Budaya Indonesia. Bandung : Alfabeta 
Rangkurti, Y. A., \& Nova, A. Pengembangan Model Pembelajaran Renang Berbasis Hukum Syariat Islam Pada SiswaSiswi Smp Negeri Di Kota Langsa. Jurnal Ilmu Keolahragaan, 18(2), 129-134.

Restela Rika, Tati2017. Tari Rampoe Sebagai Cerminan Karakteristik Masyarakat Aceh. Jurnal Panggung Vol.27 No.2.

Spradley James. 2015. Metode Etnografi. Jakarta : Kencana

Yuniarni Desni, Renny Puspita Sari. 2019. Pengembangan Multimedia Interaktif Video Senam Animasi Berbasis Budaya Khas Kalimantan Barat. Jurnal Obsesi. Vol.4 No.1 